\title{
Determination of Reservoir Capacity from Catchment Area of the Proposed Dam in the Federal University of Agriculture Makurdi, Nigeria
}

\author{
Malum Japhet Flayin ${ }^{1}$, Adenyuma Angus Peter ${ }^{2}$, Adgidzi Donald ${ }^{3}$ \\ ${ }^{1-3}$ Department of Agricultural and Environmental Engineering \\ University of Agriculture, \\ Makurdi, Benue State. Nigeria
}

\begin{abstract}
A proposed dam is to be built at a North Core watershed of the Federal University of Agriculture Makurdi. Reservoir capacity based on the mean inflow from the catchment yield into the proposed dam was assessed. The hydrological soil group of the area was studied. Mean annual rainfall for a period of 31 years (1987 to2017) was used to determine the runoff from catchment areas. Reservoir capacity was estimated using an analytical, mass curve, and residual mass curve methods. The area of the catchment was $8.82 \mathrm{~km} 2$. The mean annual runoff from catchment areas was $1222.59 \mathrm{~mm}$. The mean annual catchment yield (inflow) was 10,783,243.8m3. Cumulative inflow was used to prepare mass curve inflow into the reservoir at drafts $60 \%$ and $80 \%$ on the cumulative draft line, superimposed on the cumulative mass curve. At draft 60\%, reservoir capacity of 9,513,000m 3 resulted; at draft 80\%, 10,549,000m3. The residual mass curve of the inflow from the catchment area at a draft of 60\%, gave a reservoir capacity of 3,632,000m3, while 80\%, gave 4,426,000m3. An annual sediment discharge of 1302.02 tons was expected. A reservoir capacity of 11,000,000m3 was recommended for the proposed dam. Installment of an upstream sedimentation basin, soil conservation systems, vegetative screenings are recommended to reduce sediment load into the reservoir.
\end{abstract}

Keywords: Catchment area, Dam, Inflow Annual yield, reservoir capacity, Watershed.

\section{INTRODUCTION}

Water has traditionally been referred to as an inexhaustible gift of nature which is continuously renewed through the processes of the hydrological cycle. As free and inexhaustible as it is, its distribution and availability in various parts of the world varies. Some part experience water in abundance and sometimes in excess supply, others have moderate supply that is just enough while in some other places there is little or no adequate supply from rainfall or any other sources. Water is a necessity for the technological driven world and food security through agricultural practices of every society. It is also used for power generation, as hydropower generating plants. Human activities and agricultural productivity is at the mercy of the supply of water, hence the construction of hydraulic structures such as dams to facilitate water supply and availability [1].

A catchment area is a region where water is diverted by the means of structures to redirect water flowing from a river or stream into a dam [2]. Most dams are built on rivers or streams to store the water, while other dams, depending on the purpose of construction have inbuilt canal through which water is supplied to dam over a long or short distance from the source of water supply. The most important consideration to make in choosing a site for construction of a dam therefore is the availability of water supply sources, catchment characteristics such as inflow, dimension, elevation differential from proposed dam site, confluence (if two or more streams are involved) and distance.

This study was done to identify and determine the required design capacity of the proposed dam (reservoir) based on volume of water inflow into the catchment area of a proposed dam of Federal University of Agriculture Makurdi. And evaluate by appropriate means and method the design capacity of the dam reservoir that will be sufficient to accommodate the volume of inflow from the catchment areas.

\subsection{Metrological and Geophysical characteristics of the Study Area}

Hydrologic Soil Groups: Hydrologic Soil Groups are defined as the minimum annual steady ponded infiltration rate for a bare soil surface. The hydrologic soil group (HSG) classification system places soils into groups based on their runoff producing characteristics and depth to the average seasonal high water table (SHWT), depth to restrictive layer and saturated hydraulic conductivity of the least transmissible layer [3]. HSGs are use in soil hydrology in calculation of curve number (CN); a method 
that has become standard to predict runoff[4], based upon land use type. A curve number of "100" is interpreted as a surface that is $100 \%$ impervious. The United States Soil Conservation Service method was used in this study to estimate runoff assigned soils into four groups (A, B, C, and D) [5; 6].

Climate: The climate is determined by the geographical location of the country. The southern part of the country(Nigeria) near the coast is very humid with relatively high amounts of precipitation spread over a rainy season of six to nine months and dryer as one progress northward with steady decrease in both precipitation amount and duration of rainy season. The project area lies in the North central part of Nigeria. Meteorological stations that surrounds the area were used [7].

Rainfall: An examination of the rainfall records of Makurdi shows a definite rainy season between April and October with dry season from November to March[8].

Temperature: Air temperature is closely linked with the rate of growth and development of plants. The highest mean daily temperature are recorded during peak of dry season in March, while the lowest temperatures are recorded during the peak of rainy season(June - September) and during intense of harmttan period in December and January[7].

Evaporation: Evaporation is the conversion of water from the liquid state to the vapour state in soils and transpiration(process by which plants loose to the atmosphere). Both are referred to as evapotranspiration. Evapotranspiration largely denotes water loss. Water in reservoirs is lost due to evaporation. The rate of evaporation is determined length of sunshine, temperature and wind [9].

Geology: The area is located within the Middle Benue trough; it falls within a sedimentary basin [10]. The trough is $80-150 \mathrm{~m}$ wide and $800 \mathrm{~km}$ long, north-west, south-west trending structures. Geologically, Benue State is underlain by both sedimentary and basement rocks [11].

The lithostratigraphy of middle Benue Trough consists of shale, sandstone and limestone as the oldest dated sedimentary rocks, with hard grey to black shales and siltstones. Such deposits are believed to represent typical shallow water deposits [12].

\subsection{Reservoir (Dam) Storage Capacity}

The storage capacity of a dam or reservoir is the volume of water that a dam can accommodate at full supply level (FSL) based on design without overtopping. The storage capacity of a dam is one of the most important consideration made at the point of design, to avoid errors that may arise in the course of the design. The dam capacity is estimated by calculating the volume of water which is expected to flow into the dam from the catchment or a canal built into the dam. The storage capacity of the dam should not exceed the calculated yield from the catchment area. Capacity of dam is calculated using the formula[13;14]:

$$
Q_{r}=\frac{L \times T \times H^{\prime}}{6}
$$

Where;

$\mathrm{Q}_{\mathrm{r}}=$ Storage capacity of the reservoir in $\mathrm{m}^{3}$.

For design purpose $\mathrm{Q}_{\mathrm{r}}$ should not be less than catchment yield.

$\mathrm{L}=$ Length of the dam wall at full supply level (FSL) in $\mathrm{m}$

$\mathrm{T}=$ Throwback of the reservoir in $\mathrm{m}$ and approximately a straight line from the wall.

$\mathrm{H}^{\prime}=$ Maximum height of the dam, in $\mathrm{m}$, at FSL.

6 is a factor (conservative generally) that can be adjusted (to 5 or 4 ) with experience and local knowledge. [13].

\subsubsection{Catchment Area}

A catchment area is a river(s) or stream(s) whose flow is diverted by means of hydraulic structures into a dam. Most dams are built on a river, along a river or at the confluence point of streams flowing. The inflow from the catchment which is otherwise known as the catchment yield determines the size of the dam and gives an estimate of the design capacity of the dam that is to be built. The catchment yield $\mathrm{Y}$ is given in $\mathrm{m}^{3}$, by [13]:

$$
Y=Q \times A \times 1000
$$

$\mathrm{Y}=$ Catchment yield per unit time in a year i.e. catchment yield in an average year $\left(\mathrm{m}^{3}\right)$,

$\mathrm{Q}=$ Direct uniform runoff $(\mathrm{mm}) ; \mathrm{A}=$ Area of the catchment $\left(\mathrm{km}^{2}\right)$.

\subsubsection{Catchment area peak flood}

The peak flood is the probable maximum flood to be expected as runoff from a catchment following a rainfall of estimated intensity and duration for a selected return period taking into account the hydrological characteristics of the catchment. The peak flood gives the designer insight into the maximum runoff rate from the catchment into the dam; it is calculated using the rationally method of fuller's empirical formula which used to rationally estimate the peak flood [13] as:

$$
Q_{\max }=C \times A^{0.8}\left(1+0.8 \log T_{r}\right)\left(1+2.67 A^{-0.2}\right)
$$

where;

$\mathrm{Q}_{\max }=$ Maximum flow $\left(\mathrm{m}^{3} / \mathrm{s}\right) ; \mathrm{C}=$ Runoff coefficient; $\mathrm{A}=$ Area of the catchment in $\mathrm{km}^{2}$

$\mathrm{T}_{\mathrm{r}} \quad=$ Recurrence interval 


\subsubsection{Sedimentation of reservoirs}

In reservoirs, sedimentation is a phenomenon in which the sediment particles get deposited in the form of bed load and suspended load after separating from their origin [15]. Rainfall dominates over the surface runoff in West Africa (256 times) [16]. When a dam impounds a river, the inlet flow velocity to the reservoir decreases by part of transported sediment being deposited in the reservoir [17]. The dam and reservoir act like a sediment trap, and after depositing sediment, relatively clean water is released through the gates and weirs [18]. The amount of sediment yield depends on different factors, such as watershed area, vegetation, geology and formations of the region, as well as temporal and spatial distribution and duration and intensity of rainfall $[19 ; 20 ; 21$; 22].

\subsection{MATERIALS AND METHODS}

\subsection{Study Area}

The study area is located at the University of Agriculture Makurdi, North Core area in Makurdi Local Government Area of Benue State. The geographical location of Makurdi is at $7^{\circ} 44^{\prime}$ north, $8^{\circ} 32^{\prime}$ east. Nigeria is located at latitude $7.7^{\circ}$ and longitude $8.5^{\circ}$ and the average elevation of Makurdi is 104 meters[7] (Figs.1 and 2).

\subsubsection{Materials/equipment}

The materials that were used for the study are from:

- Topographical map of the Federal University of Agriculture Makurdi: For studying the geophysical features of the catchment area.

- Hydrological data of Makurdi: For determining annual rainfall, runoff coefficient, annual runoff from catchment and peak flood from catchment.

- Hydrologic soil group chart: For determining the hydrologic soil type of the watershed.

- Table of curve numbers: For determining the curve number of soil type from the hydrologic soil group.

- Google earth satellite and GPS locations software: For surveillance, imaging, marking out catchment areas and measurement of distance on the project area.

- Mathematical set: For reading distances and position on the topographical map.

\subsubsection{Catchment Drainage (Streams)}

From survey and site investigations as well as information from topographical map and satellite surveillance, there are three major streams that flow within the catchment area of the University identified as: stream A, stream B and stream C (Figs. 3 and 4). The three streams flow down from three separate courses to the confluence point A where the dam is to be sited (Fig. 3). The topographical map of the project area (Fig. 4) clearly shows the catchment streams, the elevation at the source of the streams and the proposed site of the dam which is at the point of their confluence behind the school chaplaincy (Chapel of the good Shepherd).The map extract in Fig. 3 shows clearly the catchment streams and their elevations from their sources. The three catchment streams are identified as:

Stream A: the stream that flows from around the ring road to the west and flows down southwards towards the college of agronomy to the point of confluence behind the school chaplaincy (Fig. 4).

Stream B: the stream that flows from North core animal farm to the east of the ring road and flows down towards the college of Agronomy, join stream A and flows together to the confluence point.

Stream C: the stream flowing behind the clinic, around it to the north and all the way to the point of confluence.

Distance of stream A to $\mathrm{D}\left(\mathrm{X}_{1} \mathrm{~cm}\right)$ was calculated using the formula:

$$
X_{1} \mathrm{~cm}=\frac{\text { stream } \text { A distance } \times \text { map scale distance to ground }}{1000}
$$

The $\mathrm{X}_{1}$ in kilometers $(\mathrm{km})$.

Stream (B) has a measured distance of $17.8 \mathrm{~cm}$ on the topographical map. Given from the $\operatorname{map}(1 \mathrm{~cm}=150 \mathrm{~m}) ; 17.8 \mathrm{~cm}=\mathrm{X}_{2} \mathrm{~cm}$

Distance of stream $B$ to $D\left(X_{2} \mathrm{~cm}\right)$ in figure 3 was calculated using the formula:

$$
X_{2} \mathrm{~cm}=\frac{\text { stream } B \text { distance } \times \text { map scale distance to ground }}{1000}
$$

The $\mathrm{X}_{2}$ in $\mathrm{km}$. Stream (C) has a measured distance of $12.3 \mathrm{~cm}$ on the topographical map. Therefore: $12.3 \mathrm{~cm}=\mathrm{X}_{3} \mathrm{~cm}$; Distance of stream $\mathrm{C}$ to $\mathrm{D}\left(\mathrm{X}_{3} \mathrm{~cm}\right)$ in figure 3 will be calculated using the formula:

$$
X_{3} \mathrm{~cm}=\frac{\text { stream } \mathrm{A} \text { distance } \times \text { map scale distance to ground }}{1000}
$$




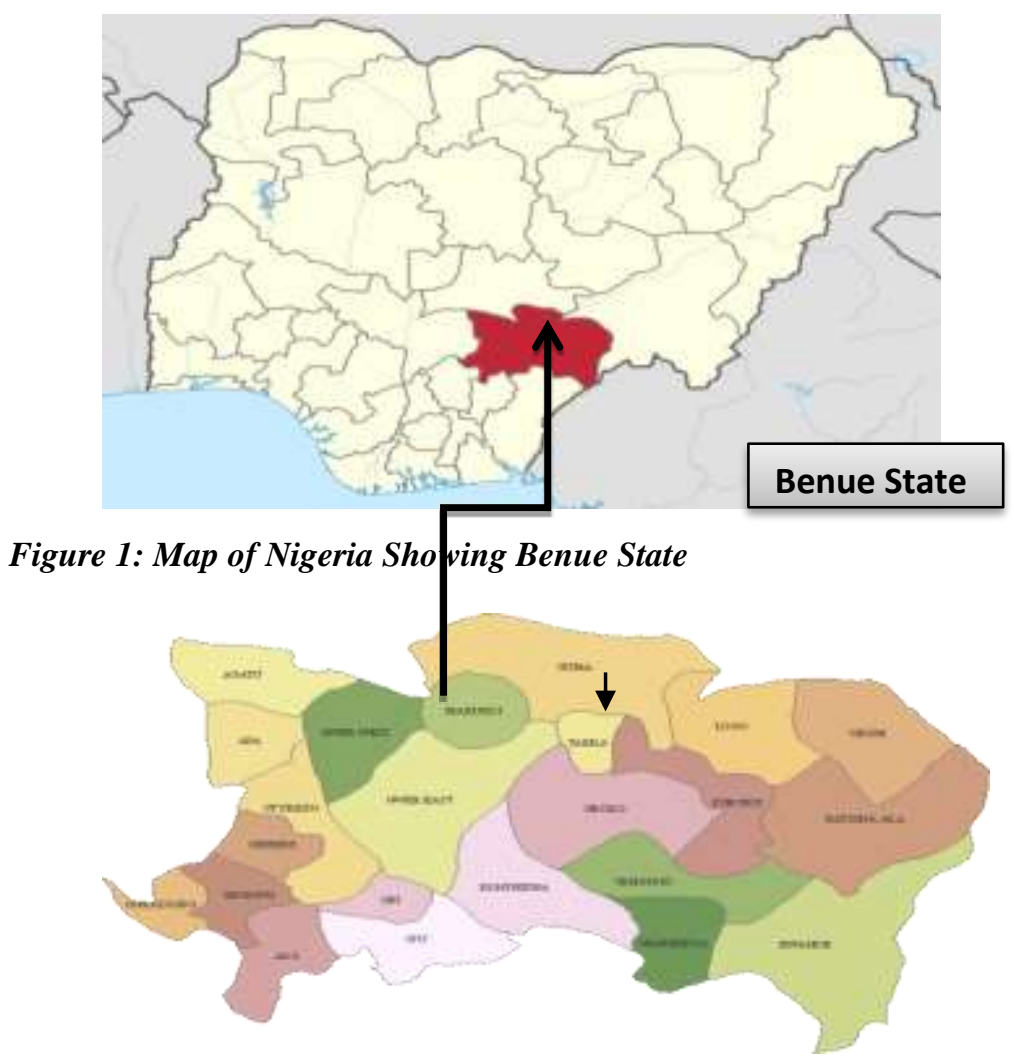

Figure 2: Map of Benue State Showing Makurdi - Project Area Source: [23].

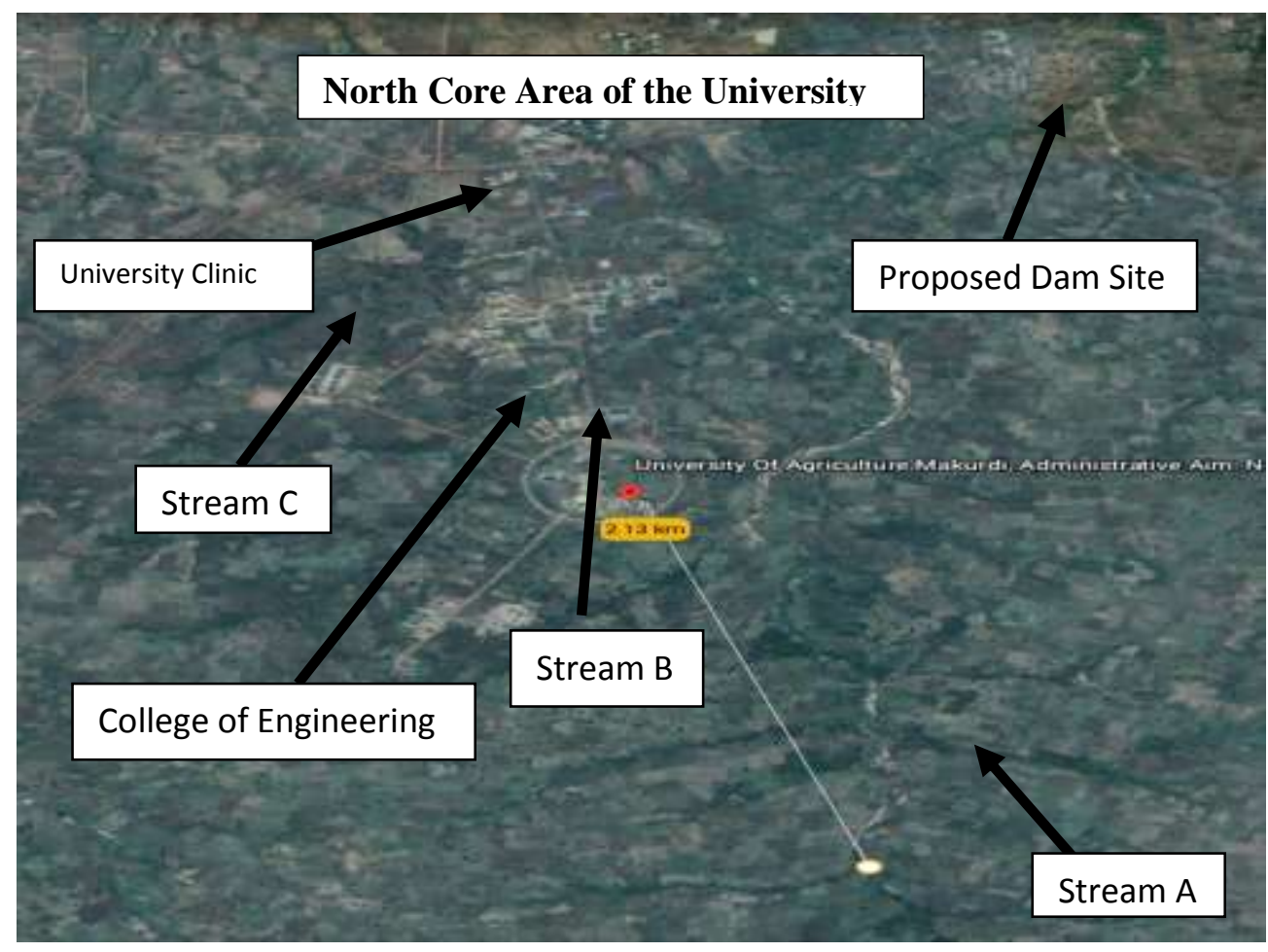

Figure 3: Google Earth Image of Project Area Showing Notable Structures on the Catchment Area Source: [24] 


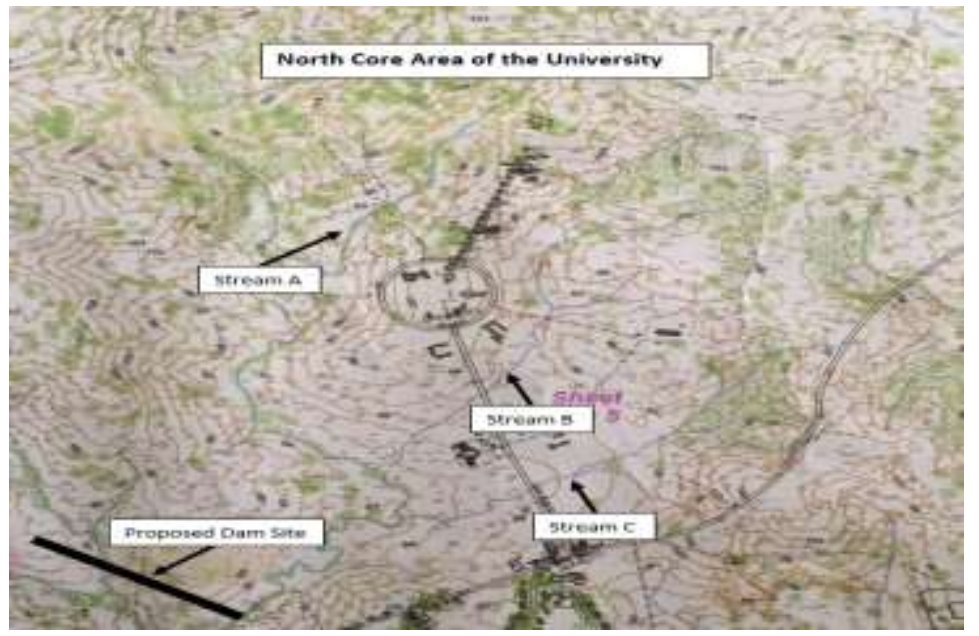

Figure 4: Topographical Map of the Project Area Showing Catchment Streams. Source: [25].

\subsection{Estimation of Catchment Streams Distance from Proposed Dam Site}

From the topographical map which has a scale of 1:15000, (1 cm on the map represent 150 meters of ground distance) [25], the length of the three catchment streams from their point of flow to the dam site of ground elevation was measured(Plate 1).

Stream (A) (Fig. 5) has a measured distance of $15.4 \mathrm{~cm}$ on the topographical map. Given from the map that $1 \mathrm{~cm}$ represents 150 meters of ground distance $(1 \mathrm{~cm}=150 \mathrm{~m})$, therefore: $15.4 \mathrm{~cm}=\mathrm{X}_{1} \mathrm{~cm}$.
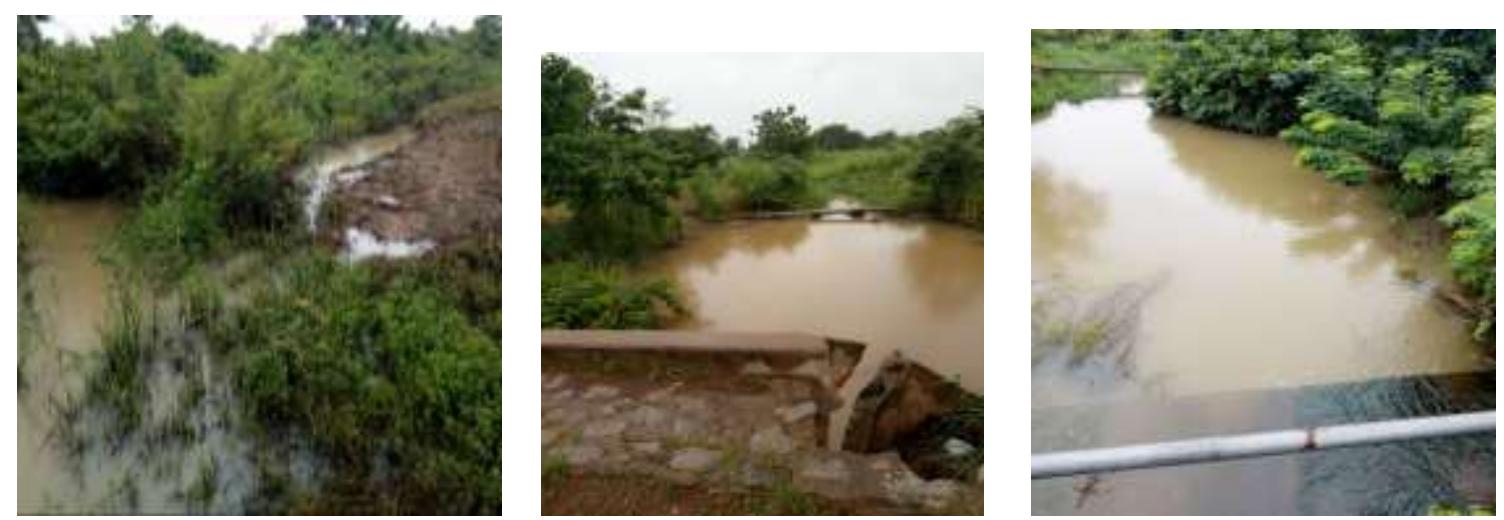

Plate 1: Catchment streams during Rainy Season into Proposed Dam Site Area Source: Site Investigation at Catchment Area.

\subsection{Determination of Reservoir Capacity}

The reservoir storage capacity will be determined on the basis of the inflow to the reservoir from the catchment (catchment yield) [26]. Three methods were used to determine the inflow from catchment to the reservoir which are;

- Rational or analytical method

- Mass curve method

- $\quad$ Residual mass curve method

\subsubsection{Rational or analytical method}

The rational method involves the use of formula, tables, chart and graphs of catchment characteristics to determine the storage of reservoir.

Catchment yield (Y): The catchment yield is the expected annual runoff from a catchment areas and is an important factor in the feasibility of a dam, height of embankment and the capacity of the dam[13]. Inflow is determined by the catchment yield which is based on the annual runoff from the catchment. The mean annual rainfall data for Makurdi for 31 years was used to estimate the runoff from the catchment areas. The runoff from the catchment area was determined using the US Soil Conservation Service (SCS), which is a method of determining the runoff from a catchment area rationally. 


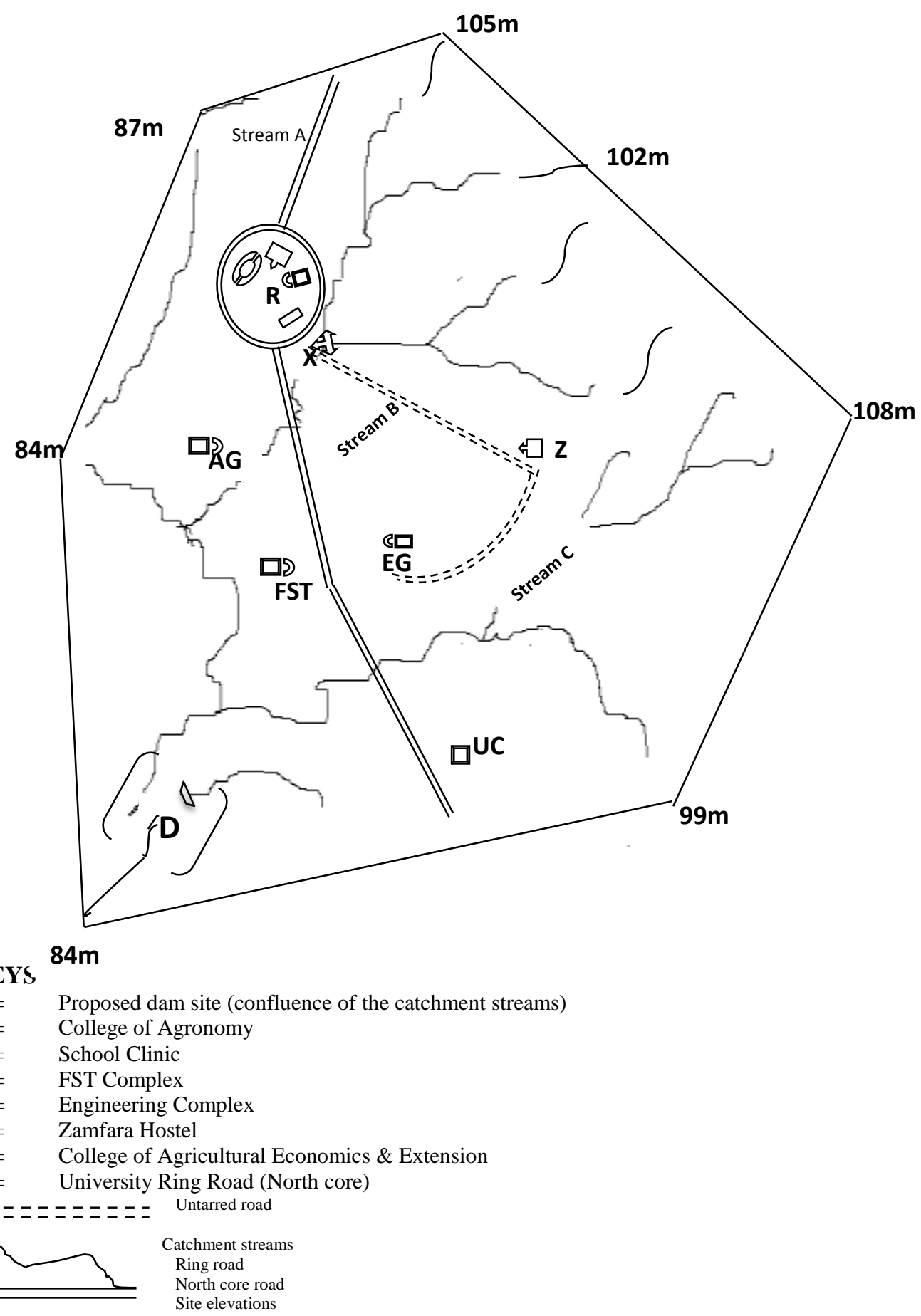

Figure 5: Map Outline Showing the Proposed Project Area and the Catchment Streams

\section{i. Determination of catchment yield (runoff) using the SCS}

The US Soil Conservation Service (SCS) runoff curve method number was used to estimate the runoff volume of the catchment. The curve number method considers losses in natural catchment such as; rain interception by vegetation, infiltration, trapping in soil due to depression and loss due to evaporation. The SCS runoff equation given by [27] as:

$$
Q=\frac{\left(P-I_{a}\right)^{2}}{P-I_{a}}+S
$$

where:

$\mathrm{Q}=$ Direct uniform runoff $(\mathrm{mm}) ; \mathrm{P}=$ Accumulated rainfall (potential maximum runoff) (mm)

$\mathrm{S}=$ Potential maximum retention after runoff begins $(\mathrm{mm}) ; \mathrm{I}_{\mathrm{a}}=$ Initial abstraction

Initial abstraction is $\left(I_{a}\right)$ is the maximum amount of rainfall absorbed without producing runoff. It includes:

All losses before runoff begin; Water retained in surface depression and water intercepted by vegetation, evaporation and infiltration. 
$I_{a}$ is highly variable but generally correlated with soil cover parameters. Through studies of many small water sheds, $I_{a}$ was found to be approximated by the empirical equation [5]:

$\mathrm{I}_{\mathrm{a}}=0.2 \mathrm{~S}$

By substituting for $I_{a}$ the equation becomes[27]:

$$
Q=\frac{(P-0.2 S)^{2}}{P+0.8 S}
$$

$\mathrm{S}$, which is the soil potential maximum retention after runoff begins, is related to the soil and cover conditions of the catchment area through the curve number $(\mathrm{CN})$. $\mathrm{CN}$ has a range of 0 to 100 , and $\mathrm{S}$ is related to $\mathrm{CN}[27]$ as:

$$
S=\frac{1000}{C N}-10
$$

The major factors that determine $\mathrm{CN}$ are: The hydrologic soil group (HSG), Cover type, Treatment, Hydrologic conditions and Runoff condition. Infiltration rates of soil vary widely and are affected by subsurface permeability and surface intake rate. Soils are classified into four hydrologic soil group, group A, group B, group C and group D according to their minimum infiltration rate[4] (Nielsen and Hjelmfelt,1998). The catchment area is an agricultural watershed of soil group C, the curve number was determined using a table of runoff curve numbers for agricultural watersheds. The catchment yield $\mathrm{Y}$ in $\mathrm{m}^{3}$ is given by [13] as:

$$
\mathrm{Y}=\mathrm{Q} \times \mathrm{A} \times 1000
$$

Where:

$\mathrm{Y}=$ Catchment yield per unit time in a year i.e. catchment yield in an average year $\left(\mathrm{m}^{3}\right)$

$\mathrm{Q}=$ Direct uniform runoff $(\mathrm{mm}) ; \mathrm{A}=$ Area of the catchment $\left(\mathrm{km}^{2}\right)$

\section{ii. $\quad$ Peak flood}

The peak flood is the probable maximum flood (PMF) to be expected from a catchment following a rainfall of estimated intensity and duration for a selected return period taking into account the hydrological characteristics of the catchment [13]FAO (2010). The peak flood was calculated using Fuller's formula[28] :

$$
\mathrm{Q}_{\max }=\mathrm{Cx} \mathrm{A}^{0.8}\left(1+0.8 \log \mathrm{T}_{\mathrm{r}}\right)\left(1+2.67 \mathrm{~A}^{-0.2}\right)
$$

where;

$$
\begin{aligned}
\mathrm{Q} & =\text { Maximum flow }\left(\mathrm{m}^{3} / \mathrm{s}\right) ; \mathrm{C}=\text { Runoff coefficient; } \mathrm{A}=\text { Area of the catchment in } \mathrm{km}^{2} \\
\mathrm{~T}_{\mathrm{r}} & =\text { Recurrence interval (taken as } 100 \text { years). }
\end{aligned}
$$

\subsubsection{Mass curve method}

A mass curve of inflow (or mass curve) is a plot of accumulated flow in a stream against time [26]. Ripple [29] determined the capacity of a reservoir by the mass curve method. This method is based solely on the historical inflow record. The reservoir mass curve has many useful applications in the design of a storage capacity, such as determination of reservoir capacity, operations procedure and flood routing [30]. The reservoir capacity was calculated using the following steps:

A mass curve of the historical stream flows (annual data) was constructed; the slope of the cumulative draft line was determined and the cumulative draft line for the reservoir was superimposed on the mass curve. Measuring the largest intercept between the mass inflow curve and the cumulative draft line gives the reservoir capacity [31]. To obtain the reservoir capacity estimation using mass curve method therefore; a stream flow interval of 31 years (1987 to 2017, 372 months) was used to get the maximum available capacity of the reservoir.

\subsubsection{Residual mass curve}

McMahon and Mein [31] (1986), defined Residual mass curve as a slightly more complicated version of the mass curve, but with a much more appropriate graphical scale for the determination of the storage size. This method is used by subtracting the mean flow from each flow value of the record, the results called residual values are plotted cumulatively and the cumulative draft line is superimposed such that the draft line is tangential to each hump of the residual curve, after that measuring the largest intercept between the mass inflow curve and the draft line.

\subsection{Sediment Yield}

The rate at which the capacity of the reservoir is reduced by sedimentation depends on: The quantity and velocity of sediment inflow; the percentage of sediment inflow trapped in the reservoir and the density of the deposited sediment. The mean annual suspended load, $\mathrm{Q}_{\mathrm{s}}$ in tons as function of mean annual discharge $\mathrm{Q}$ in cubic metres per second for various vegetal covers is given by the Fleming equation[32]:

$$
Q_{s}=a Q^{n}
$$

Where:

$\mathrm{Q}_{\mathrm{s}}=$ Sediment discharge in tonnes per annum; $\mathrm{Q}=$ is the mean annual runoff $\left(\mathrm{m}^{3} / \mathrm{s}\right)$

"a"and " $\mathrm{n}$ " are constants for various vegetal cover [33]. 


\subsection{RESULTS AND DISCUSSION}

\subsection{Results}

Three methods were used to determine the reservoir capacity based on annual inflow from catchment area. The three methods were the rational/analytical method, mass curve method and the residual mass curve method. Monthly rainfall data for a period between 1987 and 2017 was collected from the Nigeria Meteorological Agency [8] and used to estimate annual inflow from the catchment area.

\subsubsection{Rational/analytical method}

Calculating catchment yield per annum: From equation 8, potential maximum retention after runoff begins $\mathrm{S}$ is given as:

$$
S=\frac{1000}{\mathrm{CN}}-10
$$

$\mathrm{CN}$ was determined to be equal to 74 ; the value of $\mathrm{S}$ was calculated as:

$S=\frac{1000}{74}-10 ; \quad S=3.51 \mathrm{~mm}$

Direct uniform runoff $\mathrm{Q}$ in $\mathrm{mm}$ (from equation 7) is given as:

$$
Q=\frac{(P-0.2 S)^{2}}{(P+0.8 S)}
$$

Where:

$\mathrm{P}=$ Accumulated rainfall (potential maximum runoff in $\mathrm{mm}$ ); $\mathrm{S}=$ Potential maximum retention after runoff begins. Mean annual rainfall for 31 years $(1987-2017)$ was $1226.86 \mathrm{~mm}$ (Table 1); $\mathrm{P}$ is therefore equal to $1226.86 \mathrm{~mm}$. Direct uniform runoff $\mathrm{Q}$ is calculated as thus:

$$
Q=\frac{(1226.86-0.2 \times 3.51)^{2}}{1226.86+0.8 \times 3.51} ; \quad Q=1222.59 \mathrm{~mm}
$$

Direct uniform runoff $Q$ from catchment $=1222.59 \mathrm{~mm}$.

Mean annual catchment yield $\mathrm{Y}$ given in equation 9 as: $\quad Y=Q \times A \times 1000$

Where:

$\mathrm{Y}=$ Catchment yield in $\mathrm{m}^{3} ; \mathrm{Q}=$ Direct uniform runoff in $\mathrm{mm} ; \mathrm{A}=$ Area of catchment in $\mathrm{km}^{2}$ and was measured to be approximately $8.82 \mathrm{~km}^{2}$ using the Google earth software (Fig. 5).

Catchment yield: was calculated as:

$Y=1222.59 \times 8.82 \times 1000 ; \quad Y=10,783,243.8 \mathrm{~m}^{3}$

Mean catchment yield Y per annum $=10,783,243.8 \mathrm{~m}^{3}$.

Calculating peak flood from catchment: Peak from catchment was calculated using equation 10, given as:

$$
\mathrm{Q}_{\max }=\mathrm{Cx} \mathrm{A}^{0.8}\left(1+0.8 \log \mathrm{T}_{\mathrm{r}}\right)\left(1+2.67 \mathrm{~A}^{-0.2}\right) \text {. }
$$

Where:

$\mathrm{Q}=$ Maximum flow $\left(\mathrm{m}^{3} / \mathrm{s}\right) ; \mathrm{C}=$ Runoff coefficient; $\mathrm{A}=$ Area of the catchment in $\mathrm{km}^{2}$ which is $8.82 \mathrm{~km}^{2} ; \mathrm{T}_{\mathrm{r}}=$ Recurrence interval (taken as 100 years).

Runoff soil for heavy soil (group C soil in the HSG) with crop is estimated to be 0.20 [34], peak flood from the catchment is calculated as:

$Q_{\max }=0.2 \times 8.82^{0.8}(1+0.8 \log 100)\left(1+2.67 \times 8.82^{-0.2}\right) ; \quad Q_{\max }=8.09 \mathrm{~m}^{3} / \mathrm{s}$.

Table 1 gives the calculated monthly, annual and mean inflow between the periods of $1987-2017$ from the catchment to the reservoir. The mean total of the annual inflow which was calculated to be approximately $10.459 \times 10^{6} \mathrm{~m}^{3}$ gives the required design capacity of the reservoir based on the inflow from the catchment. Figure 6 is a curve of the total annual inflow between 1987 and 2017.

\subsubsection{Mass Curve Method}

This method is based solely on the historical inflow record. The reservoir capacity was determined by preparing a mass curve of the cumulative inflow between the period of 1987 and 2017. The cumulative draft line is superimposed on the mass curve. The largest intercept between the mass inflow curve and the cumulative draft line gives the required design capacity of the reservoir as the mass curve of cumulative inflow (Fig. 7). The line GH in Figure 7 is the cumulative draft line of the mass curve. A slope of $60 \%$ and $80 \%$ of the draft line is taken to determine required design storage of the reservoir [35]. At $60 \%$ of the draft line number of years was calculated as:

$\left(\frac{60}{100}\right) \times 31=19$ Years

The period of 19 years from 1993 - 2012 was taken to determine the slope of the draft line for draft $60 \%$ and slope of the draft line was calculated using the formula:

$\frac{C f_{y r 2}-C f_{y r 1}}{y r 2-y r 1}$ 
International Journal of Advances in Scientific Research and Engineering (ijasre), Vol 8 (1), January -2022

Table 1: Calculated 31 Years $\left(1987\right.$ - 2017) Monthly Inflow $\left(\mathrm{m}^{3} \times 10^{6}\right)$ from Catchment Area for the Rational/Analytical Method $(Y=Q \times A \times 1000)$

\begin{tabular}{|c|c|c|c|c|c|c|c|c|c|c|c|c|c|}
\hline Year & Jan & Feb & Mar & Apr & May & Jun & Jul & Aug & Sep & Oct & Nov & Dec & $\begin{array}{l}\text { Total annual } \\
\text { inflow (reservoir } \\
\text { Capacity) }\end{array}$ \\
\hline 1987 & 0.000 & 0.000 & 0.154 & 0.195 & 0.145 & 1.138 & 0.800 & 1.775 & 3.889 & 1.355 & 0.000 & 0.000 & 9.451 \\
\hline 1988 & 0.000 & 0.000 & 0.0 & 0.538 & 1.575 & 0.653 & 1.367 & 1.805 & 1.278 & 0.807 & 0.000 & 0.064 & 8.087 \\
\hline 1989 & 0.000 & 0.000 & 0.019 & 0.615 & 1.751 & 1.596 & 1.711 & 1.252 & 1.546 & 1.484 & 0.000 & 0.000 & 8.586 \\
\hline 1990 & 0.000 & 0.000 & 0.0 & 0.338 & 0.932 & 1.755 & 1.364 & 1.881 & 3.375 & 0.734 & 0.016 & 0.114 & 10.509 \\
\hline 1991 & 0.000 & 0.000 & 0.348 & 1.649 & 2.646 & 0.691 & 0.826 & 2.084 & 1.564 & 1.484 & 0.000 & 0.000 & 11.294 \\
\hline 1992 & 0.617 & 0.004 & 0.041 & 0.301 & 0.982 & 0.549 & 1.263 & 1.234 & 2.667 & 0.692 & 0.564 & 0.000 & 8.914 \\
\hline 1993 & 0.000 & 0.000 & 0.753 & 0.423 & 1.576 & 2.558 & 2.411 & 1.568 & 2.867 & 3.113 & 0.000 & 0.000 & 15.270 \\
\hline 1994 & 0.238 & 0.000 & 0.0 & 0.518 & 1.327 & 0.952 & 0.723 & 1.882 & 1.619 & 0.134 & 0.000 & 0.000 & 8.337 \\
\hline 1995 & 0.000 & 0.039 & 0.136 & 0.309 & 0.749 & 3.122 & 0.940 & 2.508 & 1.052 & 1.359 & 0.107 & 0.000 & 10.322 \\
\hline 1996 & 0.000 & 0.001 & 0.0 & 0.961 & 1.194 & 2.126 & 1.806 & 2.538 & 2.179 & 0.870 & 0.000 & 0.000 & 11.675 \\
\hline 1997 & 0.000 & 0.000 & 0.013 & 1.879 & 0.874 & 1.438 & 0.771 & 1.378 & 3.327 & 2.079 & 0.000 & 0.000 & 11.759 \\
\hline 1998 & 0.000 & 0.000 & 0.0 & 1.190 & 1.377 & 0.988 & 2.132 & 3.067 & 2.805 & 0.826 & 0.000 & 0.000 & 12.385 \\
\hline 1999 & 0.009 & 0.000 & 0.372 & 0.988 & 1.363 & 2.681 & 1.167 & 3.067 & 3.416 & 1.368 & 0.000 & 0.000 & 14.431 \\
\hline 2000 & 0.000 & 0.000 & 0.000 & 0.850 & 1.007 & 2.002 & 1.523 & 2.951 & 1.316 & 0.697 & 0.000 & 0.000 & 10.352 \\
\hline 2001 & 0.000 & 0.000 & 0.000 & 0.8688 & 1.223 & 2.117 & 0.847 & 2.214 & 1.908 & 0.325 & 0.000 & 0.000 & 9.508 \\
\hline 2002 & 0.000 & 0.000 & 0.363 & 0.697 & 0.969 & 1.508 & 1.657 & 1.902 & 3.113 & 0.957 & 0.177 & 0.000 & 11.344 \\
\hline 2003 & 0.000 & 0.000 & 0.000 & 0.497 & 0.263 & 1.764 & 1.051 & 1.282 & 1.221 & 0.339 & 0.297 & 0.000 & 6.715 \\
\hline 2004 & 0.000 & 0.000 & 0.069 & 0.591 & 0.647 & 1.446 & 1.498 & 1.633 & 1.435 & 1.301 & 0.006 & 0.000 & 7.596 \\
\hline 2005 & 0.000 & 0.000 & 0.194 & 0.378 & 0.798 & 1.850 & 1.256 & 0.994 & 1.406 & 0.807 & 0.000 & 0.000 & 7.685 \\
\hline 2006 & 0.440 & 0.000 & 0.117 & 0.230 & 2.438 & 0.969 & 2.846 & 1.897 & 2.022 & 0.913 & 0.000 & 0.000 & 11.874 \\
\hline 2007 & 0.000 & 0.000 & 0.077 & 1.102 & 1.504 & 1.852 & 1.009 & 2.405 & 1.922 & 1.933 & 0.014 & 0.000 & 11.818 \\
\hline 2008 & 0.026 & 0.000 & TR & 1.306 & 1.287 & 1.641 & 0.719 & 2.471 & 0.732 & 0.745 & 0.009 & 0.000 & 8.938 \\
\hline 2009 & 0.018 & 0.000 & 0.026 & 1.588 & 1.678 & 2.113 & 0.759 & 2.428 & 1.239 & 2.506 & 0.011 & 0.000 & 12.367 \\
\hline 2010 & 0.000 & 0.000 & 0.111 & 0.276 & 1.188 & 1.053 & 1.699 & 1.571 & 2.695 & 1.030 & 0.211 & 0.000 & 9.837 \\
\hline 2011 & 0.000 & 0.000 & 0.000 & 0.688 & 1.259 & 0.533 & 0.767 & 1.917 & 2.399 & 2.597 & 0.000 & 0.000 & 10.161 \\
\hline 2012 & 0.000 & 0.004 & 0.000 & 1.263 & 1.281 & 1.416 & 3.104 & 1.537 & 2.564 & 1.756 & 0.241 & 0.000 & 13.166 \\
\hline 2013 & 0.000 & 0.000 & 0.389 & 1.084 & 1.618 & 1.250 & 2.149 & 1.155 & 2.516 & 1.107 & 0.000 & 0.089 & 11.358 \\
\hline 2014 & 0.035 & 0.035 & 0.297 & 0.497 & 1.416 & 1.455 & 1.140 & 2.422 & 2.707 & 0.887 & 0.233 & 0.041 & 11.167 \\
\hline 2015 & 0.000 & 0.986 & 0.034 & 0.156 & 0.328 & 0.208 & 1.232 & 2.991 & 1.123 & 0.731 & 0.148 & 0.000 & 7.938 \\
\hline 2016 & 0.000 & 0.000 & 0.419 & 0.804 & 2.099 & 0.436 & 1.902 & 1.886 & 2.372 & 1.024 & 0.000 & 0.000 & 10.941 \\
\hline 2017 & 0.000 & 0.000 & 0.000 & 0.761 & 1.927 & 1.066 & 1.041 & 1.978 & 1.017 & 0.652 & 0.005 & 0.000 & 8.449 \\
\hline Mean & 0.198 & 0.178 & 0.218 & 0.759 & 1.249 & 1.462 & 1.415 & 1.989 & 2.142 & 1.199 & 0.145 & 0.077 & 10.459 \\
\hline Min & 0.018 & 0.001 & 0.019 & 0.156 & 0.145 & 0.208 & 0.719 & 0.994 & 0.732 & 0.134 & 0.006 & 0.041 & 6.715 \\
\hline Max & 0.617 & 0.986 & 0.753 & 0.986 & 2.646 & 3.122 & 3.104 & 3.067 & 3.889 & 3.113 & 0.564 & 0.114 & 15.270 \\
\hline
\end{tabular}

Where:

$\mathrm{Cf}_{\mathrm{yr} 2}=$ Cumulative inflow at $\mathrm{yr} 2 ; \mathrm{Cfy}_{\mathrm{yr} 1}=$ Cumulative inflow at $\mathrm{yr} 1$

yr1 $=$ First year $; \quad$ yr2 $=$ Last year. For draft $60 \%$ yr1 $=1993 ;$ and yr2 $=2012$,

$\mathrm{Cf}_{2012}=272.381 \times 10^{6} \mathrm{~m}^{3}$ (Table1 and Fig. 7); $\mathrm{Cf}_{1993}=72.111 \times 10^{6} \mathrm{~m}^{3}$ (Table 1, Fig.7).

Slope for draft at $60 \%=\frac{(272.381-72.111) \times 10^{6} \mathrm{~m}^{3}}{2012-1993}=10.540 \times 10^{6} \mathrm{~m}^{3}$

Slope for draft at $60 \%=10.540 \times 10^{6} \mathrm{~m}^{3}$.

Where:

$\mathrm{Y}=$ Catchment yield in $\mathrm{m}^{3} ; \mathrm{Q}=$ Direct uniform runoff in $\mathrm{mm}$;

$\mathrm{A}=$ Area of catchment in $\mathrm{km}^{2}$ and was measured to be approximately $8.82 \mathrm{~km}^{2}$ using the Google earth software (Fig. 5).

Measuring largest intercept between the mass inflow curve and the draft line, required reservoir capacity from cumulative curve $=$ $294.6 \times 10^{6} \mathrm{~m}^{3}$.

Reservoir capacity per annum $=\frac{294.6 \times 10^{6}}{31}=9.513 \times 10^{6} \mathrm{~m}^{3}$

Reservoir capacity for draft at $60 \%$ per annum $=9.513 \times 10^{6} \mathrm{~m}^{3}$.

For draft at $80 \%$ : 
$\frac{C f_{y r 2}-C f_{y r 1}}{y r 2-y r 1}$

Where:

$\mathrm{Cf}_{\mathrm{yr} 2}=$ Cumulative inflow at $\mathrm{yr} 2 ; \mathrm{Cfy}_{\mathrm{yr} 1}=$ Cumulative inflow at $\mathrm{yr} 1$

yr1 = First year; $\quad$ yr2 $=$ Last year. For draft at $80 \%$ yr1 $=1989$ and yr2 $=2014$,

$\mathrm{Cf}_{2014}=294.906 \times 10^{6} \mathrm{~m}^{3}$ (Fig. 7); $\mathrm{Cf}_{1989}=26.124 \times 10^{6} \mathrm{~m}^{3}$ (Table 2, Fig.7)

Slope for draft at $80 \%=\frac{(294.906-26.124) \times 10^{6} \mathrm{~m}^{3}}{2014-1989}=10.751 \times 10^{6} \mathrm{~m}^{3}$

Slope for draft at $80 \%=10.751 \times 10^{6} \mathrm{~m}^{3}$

Measuring largest intercept between the mass inflow curve and the draft line, required reservoir capacity from cumulative curve $=$ $313.8 \times 10^{6} \mathrm{~m}^{3}$.

Reservoir capacity per annum $=\frac{313.8 \times 10^{6}}{31}=10.123 \times 10^{6} \mathrm{~m}^{3}$

Required design capacity of reservoir for draft at $80 \%$ per annum $=10.123 \times 10^{6} \mathrm{~m}^{3}$.

\subsubsection{Residual mass curve method}

This method is used by subtracting the mean flow from each inflow value of Table 1, the results called residual values are plotted cumulatively and the cumulative draft line is superimposed such that the draft line is tangential to each hump of the residual curve, after that measuring the largest intercept between the mass inflow curve and the draft line. Mean inflow is 10,459,000 $\mathrm{m}^{3}$ (Table 1). Fig. 8 is the residual mass of curve of the cumulative residual inflow from catchment. A draft of $60 \%$ and $80 \%$ is taken to estimate reservoir capacity. Line EF on the residual mass curve corresponds to draft $60 \%$ on the mass curve and the estimated reservoir capacity is $3.632 \times 10^{6} \mathrm{~m}^{3}$. Line IJ corresponds to draft $80 \%$ on the residual mass curve and the estimated reservoir capacity is $4.426 \times 10 \mathrm{~m}^{3}$.

3.1.4 Calculating sediment discharge from catchment

Sediment discharge from catchment to reservoir will be estimated using Fleming's equation (equation 11) given as:

$\mathrm{Q}_{\mathrm{s}}=\mathrm{aQ}^{\mathrm{n}}$

$\mathrm{Q}_{\mathrm{s}}=$ Sediment discharge in tonnes; $\mathrm{Q}=$ is the mean annual runoff $\left(\mathrm{m}^{3} / \mathrm{s}\right)$

"a" and "n" are constants for various vegetal covers. Mean annual runoff of $10.549 \times 10^{6} \mathrm{~m}^{3}$.

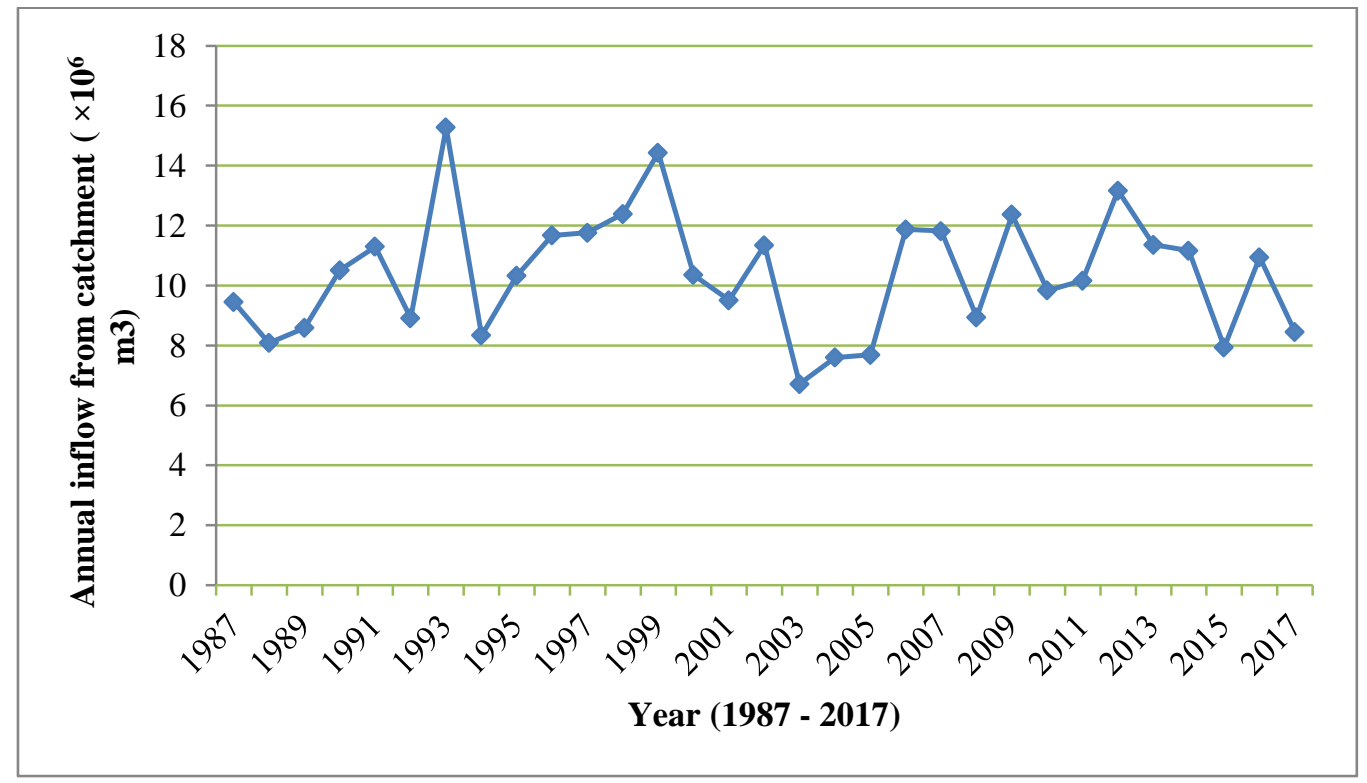

Figure 6: Inflow Hydrograph of catchment (1987 - 2017) 
International Journal of Advances in Scientific Research and Engineering (ijasre), Vol 8 (1), January -2022

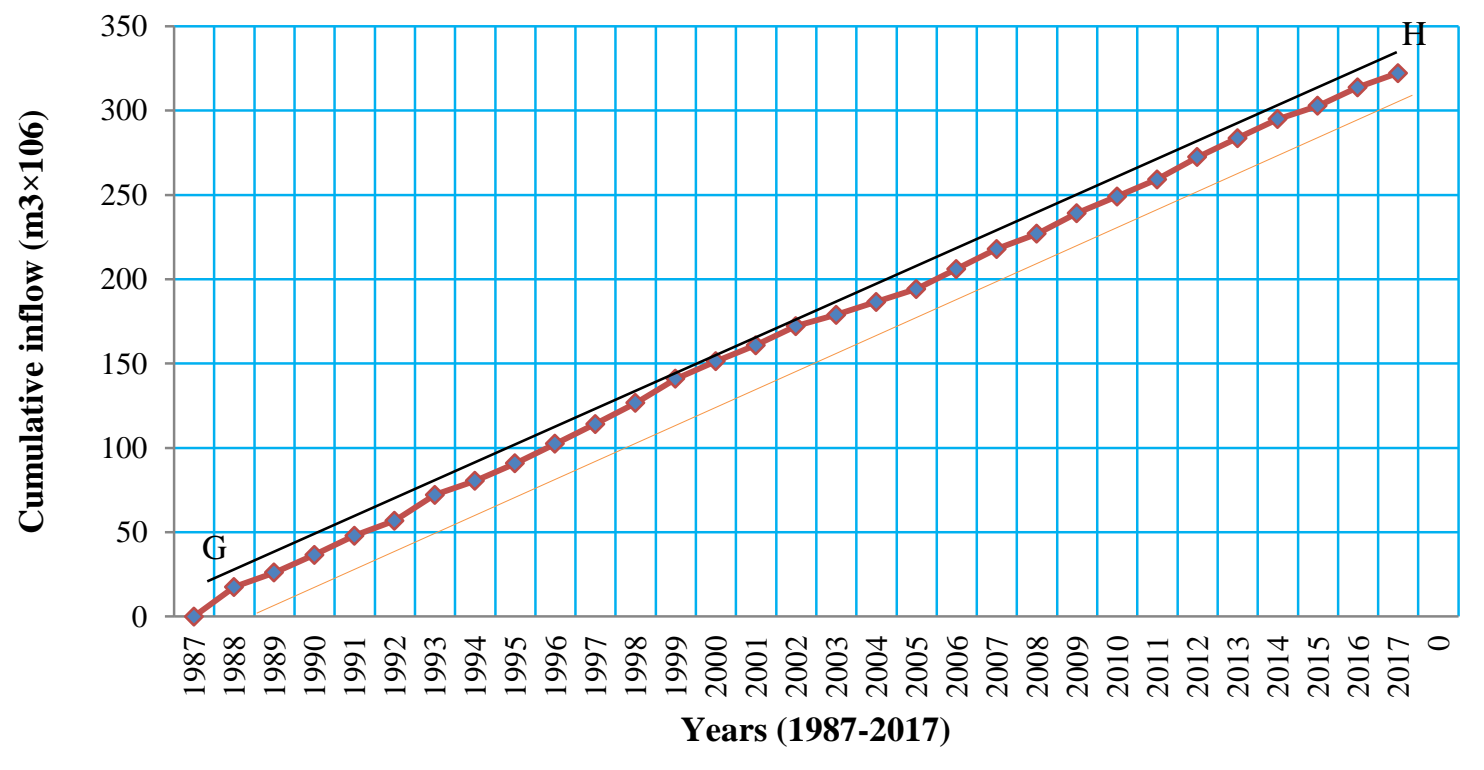

Figure 7: Mass curve of cumulative inflow $(1987$ - 2017)

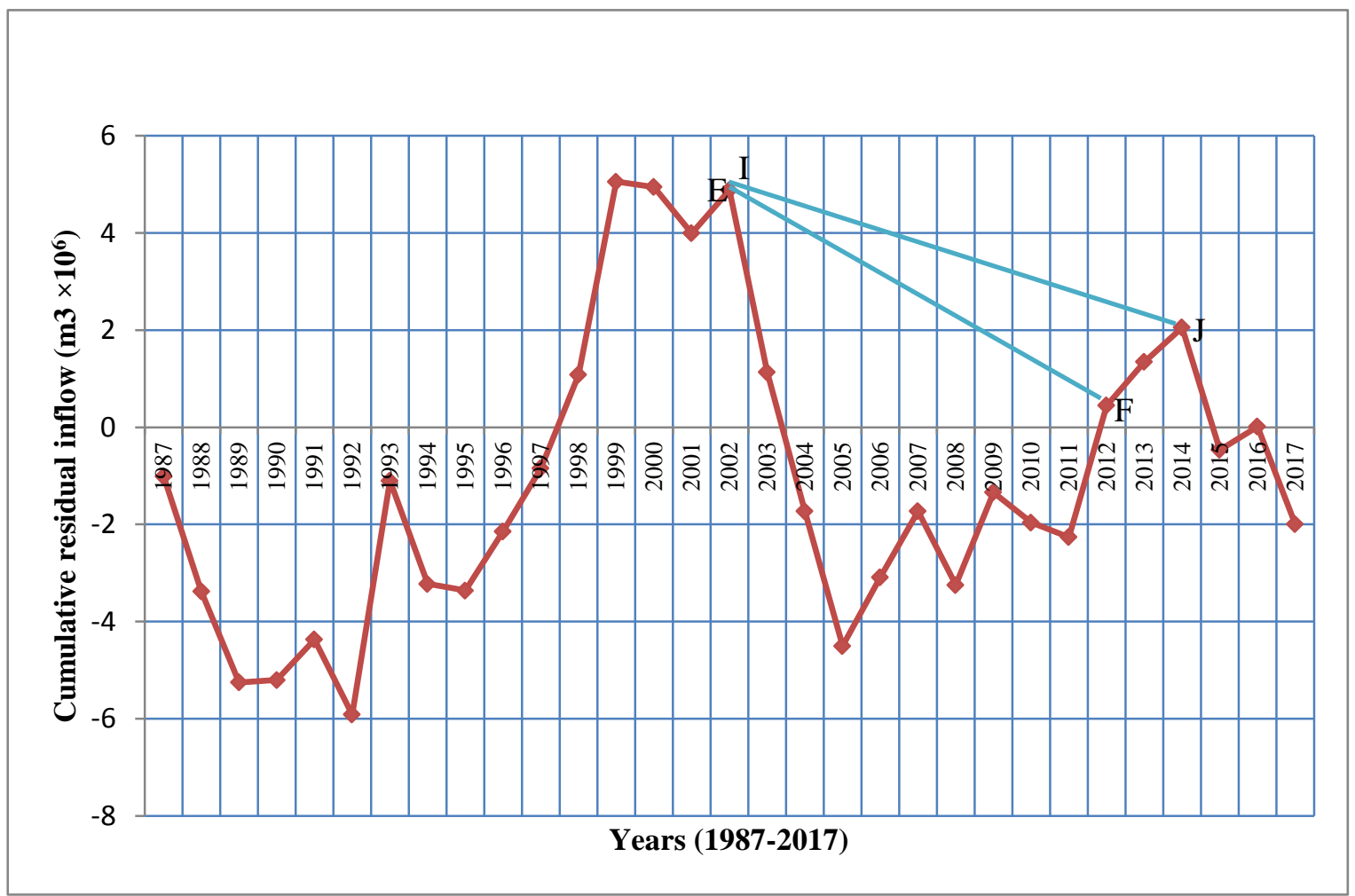

Figure 8: Residual mass curve of cumulative residual inflow (1987 - 2017)

Mean annual runoff in $\frac{\mathrm{m}^{3}}{\mathrm{~s}}=\frac{10.549 \times 10^{6}}{24 \times 60 \times 60 \times 365} \quad=0.33 \mathrm{~m}^{3} / \mathrm{s}$

Mean annual runoff in $\mathrm{m}^{3} / \mathrm{s}=0.33 \mathrm{~m}^{3} / \mathrm{s}$

Catchment is made of coniferous forest and tall grassland, "a" is 3196 and " $n$ " is 0.82 .

Sediment discharge, $\mathrm{Q}_{\mathrm{s}}=3196 \times 0.33^{0.82} \mathrm{~m}^{3} / \mathrm{s}$; Sediment discharge, $\mathrm{Q}=1302.02$ tonnes per annum. 


\subsection{Discussion}

\subsubsection{Rational/analytical method of determining the reservoir capacity}

In this method, an analysis of rainfall and inflow from catchment per month of the year is made to determine the required design capacity of dam from the catchment yield. The expected catchment yield (annual runoff) is estimated from the annual rainfall of Makurdi from record of 31 years (1987 to 2017). Catchment characteristics were investigated during field-work at the catchment to determine its runoff properties. The catchment area is made up of soil of fine texture, having slow infiltration rate when thoroughly wet hence impeding the downward movement of water (infiltration). The soil has a slow rate of transmission. From the catchment investigation, the catchment soil is of the hydrologic soil group C(Soils having a slow infiltration rate). The catchment area consists of good pasture and grassland, with portions used for mild farming of tuber, legume and grain (rice) crops. From the runoff curve numbers for agricultural lands (Table 1), the catchment soil HSG group C has a runoff curve number of 74 . The analytical method gives an approximate value of the required design capacity of the reservoir based on the inflow from catchment. The reservoir capacity was calculated to be approximately $10,783,243.8 \mathrm{~m}^{3}$. With a time reoccurrence of 100 years and a runoff coefficient of 0.2 , the peak flood from catchment was estimated to be $8.02 \mathrm{~m}^{3} / \mathrm{s}$. Mean annual inflow from catchment was calculated to be $10.549 \times 10^{6} \mathrm{~m}^{3}$.

\subsubsection{Mass curve method}

The graph of the mass curve is given in Fig.7. The cumulative inflow from catchment is given in Table 2. A draft at $60 \%$ and $80 \%$ was taken on the draft line GH (Fig. 7) to estimate the reservoir capacity. For draft at $60 \%$, the required reservoir capacity was $294.6 \times 10^{6} \mathrm{~m}^{3}$ and $9.513 \times 10^{6} \mathrm{~m}^{3}$ per annum. For draft at $80 \%$, the required capacity was $313.8 \times 10^{6} \mathrm{~m}^{3}$ and $10.123 \times 10^{6} \mathrm{~m}^{3}$.

\subsubsection{Residual mass curve method}

The residual curve of the inflow is given in Fig. 8. The residual curve gives the residual reservoir capacity for dry periods; the curve gives the least design capacity of reservoir sufficient to hold the inflow from the catchment. A draft at $60 \%$ and $80 \%$ was used to estimate reservoir capacity. Line EF (Figure 8) represents draft at 60\% and line IJ (Fig. 8) represents draft of 80\%. The intercept between the mass inflow curve and the draft line gives the required design capacity of the reservoir. For draft at $60 \%$, reservoir capacity is $3.632 \times 10^{6} \mathrm{~m}^{3}$ and for draft at $80 \%$, reservoir capacity is $4.426 \times 10^{6} \mathrm{~m}^{3}$. The comparative reservoir capacities by the 3 different methods (Analytical, Mass Curve and Residual Mass Curve) are as shown in Table 2 below.

Table 2: Comparison of the Reservoir Capacity by Different Methods

\begin{tabular}{|c|c|}
\hline Method & Storage Estimate $\left(\times 10^{6} \mathrm{~m}^{3}\right)$ \\
\hline Analytical method & 10.783 \\
\hline Analytical method (Tabulated) & 10.549 \\
\hline Mass curve method (draft at $60 \%$ ) & 9.513 \\
\hline Mass curve method (draft at $80 \%$ ) & 10.123 \\
\hline Residual mass curve method (draft at $60 \%$ ) & 3.632 \\
\hline Residual mass curve method (draft at $80 \%$ ) & 4.426 \\
\hline
\end{tabular}

\section{CONCLUSION AND RECOMMENDATION}

\subsection{Conclusions}

Three methods (Analytical, Mass Curve and Residual Mass Curve) were used in determining reservoir capacity. Monthly and annual mean flow data calculated from monthly rainfall data for a period between 1987 and 2017 were used as input data of case study.

The highest reservoir capacity resulted from the Analytical method and the Mass Curve method for draft at $80 \%$ which were $10.783 \times 10^{6} \mathrm{~m}^{3}$ and $10.123 \times 10^{6} \mathrm{~m}^{3}$ respectively. The least resulted from the Residual Mass Curve Method for draft at $60 \%$ which was $3.623 \times 10^{6} \mathrm{~m}^{3}$. The Residual Mass Curve gives the minimum allowable reservoir capacity for dry periods which can be taken as dead storage. It is observed that the year 2002 shows maximum reservoir storage capacity and the year 1992 shows the minimum. Sediment yield from catchment areas into the reservoir was estimated to be 1302.02 tonnes per annum. The reservoir capacity can be used in addition to other water requirements within the University community to generate hydroelectricity.

\subsection{Recommendation}

It is recommended that; the Analytical method should be used to size the capacity of the reservoir. Sedimentation basins should be installed at the upstream course of the catchment area to reduce sediment load into the reservoir. The use of vegetative screens, 
soil conservation methods (terraces), installation of sluice gates and dredging of settled materials at appropriate levels should be incorporated into design of the dam. Full feasibility studies for hydropower generation should be carried out.

\section{REFERENCES}

[1] A.Hesham, U. Asl1, and G. Salem, Comparison of different techniques about reservoir capacity calculation at sami soy dam sandalcık dam. CBUJS, 14(1), 2017, Pp23-29.

[2] HCA(Hill Country Alliance), Water Catchment Areas (Water sheds), 2015.https://www.hill countryalliance. org /water-catchment-areas. Accessed October, 2020

[3] A. A. Suleiman and J. T. Ritchie, Estimating saturated hydraulic conductivity from soil porosity. https:// www. research gate. net/publication/269802021. Accessed March, 2021.

[4] R.D.Nielsen and A.T.Hjelmfelt,(1998). Hydrologic soil group assessment, water resources engineering. In Abt, young-pezeshk, and watson (eds.), Proc. of intern. water resources eng. conf., am. soc. civil engr. 1998, Pp. 1297-1302.

[5] R. R. Serthi, Methods and estimation of excess rainfall(runoff) theory and practical, 2018. http:// www.dowro disha. gov.in /TrainingProgramme /2018/ICAR/ materials/ dy2/. Accessed, May, 2021.

[6] WSDOT (Washington State Department of Transportation), (2014). Table of curve numbers - highway runoff manual, M 31, 2014, 16-04.

[7] E.I. Ocheja, Determination of inflow design flood and its effect on dam safety, PhD Dissertation, Department of agricultural and environmental engineering, Federal University of Agriculture Makurdi, Benue State, Nigeria, 2016.

[8] NMA (Nigerian Meteorological Agency),Tactical air command air-port - climatological data, Makurdi ,Nigeria, 2017.

[9] H. Dawei, Concise hydrology. first edition, .ISBN 978-87-76-81 536-3. 2010.

[10] O. K. Likkason, G. P. Singh and N. K. Samaila, A Study of the middle benue trough (Nigeria) based on geological application and analyses of spectra of aeromagnetic data. Energy Sources, Part A: Recovery, utilization, and environmental effects,35(8),706-716. http://dx. doi.org /10.1080/15567036. 2010.514588. Accessed,June, 2021.

[11] H.T. Jika andL.I. Mamma, Application of electromagnetic profilling and electrical resistivity sounding in hydro -geological studies. a case study of Vandeikya area, central Nigeria. IJSTR.3(2), 2014, Pp 179-190.

[12] J.H.Terkula and M.L.Ikechukwu, Groundwater potential south core university of agriculture community Makurdi central Nigeria-impact: IJNSS, 2 (6), 2014.

[13] FAO (Food and Agricultural Organisation of the United Nations), Manual on small earth dams - a guide to siting, design and construction, Paper 64, 2010.

[14] FAO (Food and Agricultural Organisation of the United Nations), (2019). Estimate of water Storage, 2019. http://www.fao.org/tempref/FI/CDrom/FAO_Training/General.htm. Accessed, June, 2021.

[15] S. Dutta, Soil erosion, sediment yield and sedimentation of reservoir: a review article - model. Earth Syst. Environ. 2 (123), 2016.

[16] E.J.Roose, Approach to the definition of rain erosivity and soil erodibility in west Africa. In: M.D.Bood and D.Gabriels (eds), Assessment of erosion.Wiley, NY, 1980. pp 53-164.

[17] Y.H.E Chen, V.Richardson and J.L.Lopez, Mathematical modeling of sediment deposit in reservoirs. J. hydraulic engineering. ASCE, 104: 1978.1605-1616.

[18] K. Kolhari, Watershed management studies and optimum exploitation of the dam reservoirs, Proc. 4th educational workshop of Technical Committee of Dam Hydraulics, 1999, 5 p.

[19] W.H.Wischmeir, Erosion rates and contributing factors in semiarid regions.Int. seminar on water and soil utilization, Brookings, South Dakota, 1960.

[20] N.W.Hudson, The factors determining the extent of soil erosion. Soil conservation and management in the humid tropics. Bureau of Indian standards, New Delhi, India, 1975.

[21] ASCE (American Society of Civil Engineers), Relationships between morphology of small streams and sediment yield. J. hydrol div 108: 1982.1328-1365.

[22] A.H.Y. Khalaj and F.Karimzadeh, An investigation of sedimentation in watersheds and dam reservoirs (Case study: Ekbatan dam in Hamadan). Proc. 4th educational workshop of technical committee of dam hydraulics, 1999, 30p.

[23] A.Terkula, List of Benue state local government caretaker committee chairmen and secretaries, Ati Terkula's Blog, 2015. https:// atiterkula.Wordpress.com. Accessed, October, 2020. 
[24] Google earth image of north core, federal university of agriculture Makurdi, Nigeria ,2020.

[25] FUAM (Federal University of Agriculture Makurdi), Topographical map, department of works and planning Benue State, Nigeria, 2010.

[26] R. Sonowal, Water engineering - how to determine capacity of a storage reservoir,2014. http://www .engineeringenotes.com/water-engineering-2/storage reservoir. Accessed, August, 2020.

[27] HydroCAD, Storm water modeling - copyright hydroCAD software solutions LLC, 2019.

[28] A. Saha, (2002). Quick estimation of peak discharge of north bengal catchments, Pro.International Conference on Water Related Disaster (ICWRD), Indian Association of Hydrologists (IAH),Kolkata. Analysis and practice in water resources engineering for disaster mitigation, Vol.-1, 2002. pp.-46-51.

[29] W. Ripple, Capacity of storage reservoirs for water supply. Minutes of proc., p. 71. 1883.

[30] Bharali, B., Estimation of reservoir storage capacity by using residual mass curve. Journal of civil engineering and environmental technology, 2(10), 2015. pp. 15-18.

[31] T.A. McMahon and R.G.Mein, River and reservoir yield, Colorado, WR Publications. 1986.

[32] P.Chuenchum, M. Xu and W.Tang, Estimation of soil erosion and sediment yield in the lancang-mekong river using the modified Revised Universal Soil Loss Equation and GIS techniques, 2020. ,http//www. mdpi.com / journal/water. 12(135);doi:103390/w12010135.

[33] J.Pak, M.Fleming, W. Scharffenberg, and P.Ely, Soil erosion and sediment yield modeling with the hydrologic modelling system(hec-hms). World environmental and water resources congress, Ahupua'a, 2008. https://www. research gate.net/ publication /269128920. Accessed June, 2021.

[34] SWRCB (State Water Resources Control Board California), The clean water team guidance compendium for watershed monitoring and assessment, State water resources control board 5.1.3 FS-(RC), 2011.

[35] H. Alrayess,U.Zeybekoğlu and A.Ulke,Different design techniques in determining reservoir capacity. Pro.10th world congress of EWRA on water resources and environment, Athens, Greece, 2017. 